\title{
UJI AKTIVITAS ANTIMIKROBA EKSTRAK KULIT BUAH NAGA (Hylocareus costarisensis) TERHADAP E.coli, Staphylococcus aureus, DAN Candida albicans
}

\author{
Dewi Yudiana Shinta ${ }^{1)}$, Adi Hartono ${ }^{2)}$ \\ ${ }^{1)}$ Sekolah Tinggi Ilmu Kesehatan Perintis Padang \\ ${ }^{2)}$ Blk Padang \\ Jalan Adinrgoro KM 17 Simpang Kalumpang Padang \\ Email:dyshinta@ymail.com
}

\begin{abstract}
Hylocareus costarisensis more commonly known as red dragon fruit are beneficial as antioxidant and a source of natural pigments and potentially as antimicrobial. Journal of Food Research points out that the content of Phenol in the peel of red dragon fruit is greater than the the red dragon fruit itself. Phenol contained in the dragon fruit peel can be useful as antimicrobial because it can lower the surface tension of the microbial. This study therefore aims to figure out whether there is an effect the phenol of Red Dragon Fruit Peel (Hylocareus Costarisensis) extract on the ability to block the growth of microbial patogent such as E.coli, Staphylococcus aureus, and Candida albicans and to figure out the compounds found in in the dragon fruit peel . This research employs statistical analysis experiment design by using One Way ANOVA test. The concentration of Red Dragon Fruit Peel extract used was 0,4 gr, 0,8 gr, 1,4 gr, 1,8 gr, 2,0 gr and positive control concentration thinning microbial $1,8 \mathrm{x} \quad 10^{3} \mathrm{Cell} / \mathrm{ml}$. These studies demonstrated that the antimicrobial compounds in extract of Red Dragon Fruit Peel is Acetic Acid, Formic Acid and Phenol. This research also indicates that the bigger dose of Red Dragon Fruit Peel, the greater power ability to block the growth. The ability to block the growth of microbial is statistically significant $(\mathrm{p}<0,05)$ after giving of Red Dragon Fruit Peel extract.
\end{abstract}

Key words : Extraction of Hylocareus Costarisensis, E. coli, Staphylococcus aureus, Candida albicans.

\section{PENDAHULUAN}

Buah naga (Hylocereus polyrhizus) merupakan herbal kaya akan vitamin yang berkhasiat untuk membantu proses pencernaan karena seratnya, mencegah kanker usus dan diabetes, menetralisir zat beracun seperti logam berat, serta membantu mengurangi kadar kolesterol dan tekanan darah tinggi. Kulit buah naga merah selain bermanfaat sebagai antioksidan dan sumber pigmen alami (Anastasia, 2010), juga dapat berpotensi sebagai antimikroba (Hui, 2009). Kulit dan daging buahnya juga mengandung berbagai macam senyawa seperti flavonoid, thiamin, niacin, pyridoxine, kobalamin, fenolik, polifnol, karoten, dan phytoalbumin ( Jaafaret al., 2009), serta betalain (Woo et al., 2011). Betalain adalah pigmen bersifat polar yang terdiri atas betasianin dan betaxantin (Wybraniec et al., 2006). Senyawa senyawa tersebut memiliki potensi sebagai zat antimikroba.

Selain itu, Sasina, S., (2012) dalam Jurnal of Food Research menyatakan kandungan total fenol dalam kulit dan daging buah naga merah yaitu sebesar 1.049,18 mgGAE/100g dan $561,76 \mathrm{mgGAE} / 100 \mathrm{~g}$. Total fenol berbanding lurus dengan aktivitas antioksidan pada kulit 
dan daging buah naga. Fenol yg banyak pada kulit buah naga dapat berkhasiat sebagai antibakteri karena fenol dapat menurunkan tegangan permukaan bakteri.

Buah naga merah yang masih banyak dimanfaatkan adalah daging buahnya, sedangkan kulitnya belum lazim untuk dimakan dan menjadi limbah. Limbah kulit tersebut belum dimanfaatkan secara optimal, oleh karena itu, efektivitas ekstrak kulit buah naga merah (H. Polyrhizus) sebagai antimikroba terhadap mikroba patogen perlu diteliti. Sehingga kulit buah naga tidak hanya bernilai limbah melainkan dapat memperkecil produksi limbah di lingkungan. Penelitian mengenai kemampuan kulit buah naga merah sebagai antioksidan alami sudah banyak diteliti, sedangkan efektivitasnya sebagai antimikroba belum diteliti. Oleh karena itu peneliti melakukan penelitian tentang efektivitas ekstrak kulit buah naga merah sebagai antimikroba terhadap mikroba pathogen $E$ coli, Staphylococcus aureus, dan Candida albicans.

\section{METODA PENELITIAN}

\section{Cara pembuatan ekstrak kulit buah naga} (Hylocareus costarisensis) Metode Ekstraksi Secara Maserasi (Basile et al, 1998)

Ekstraksi dilakukan terhadap sampel kulit buah naga (Hylocareus costarisensis) Sampel dalam bentuk segar dibersihkan dengan air. Pengeringan dilakukan pada suhu ruang (dibiarkan selama 14 hari).

Ekstraksi dilakukan secara maserasi dengan menimbang sebanyak 500 gram sampel dengan menggunakan $500 \mathrm{ml}(250 \times 2)$ pelarut etanol selama 3 x 24 jam dan digoyang dengan penggoyang (shaker). Selanjutnya campuran disaring. Kedua filtrate yang didapat, dicampur kemudian dipekatkan dengan rotavapor pada suhu $60^{\circ} \mathrm{C}$ dengan tekanan rendah $(13,5$ $\mathrm{kgf} / \mathrm{cm}^{2}$ ). Untuk analisa kualitatif digunakan alat GC-MS .
2. Peremajaan
mikroba
Staphylococcus aureus, Candida albicans

Baketri E.coli di remajakan menggunakan media endo agar dan bakteri Staphylococcus aureus diremajakan menggunakan media Mannitol Salt Agar. Untuk membuktikan bakteri tersebut dilakukan pewarnaan Gram sederhana kemudian dilakukan tes IMVCMU dan TSIA. Pada bakteri Staphylococcus aureus dilakukan tes katalase dan koagulase. Sedangkan Candida albicans diremajakan pada media Potato Dextrosa Agar lalu dilakukan pewarnaan Gram.

Koloni jamur yang terpisah diambil secara aseptis dengan jarum ose dan digoreskan pada media Nutrient Agar, kemudian diinkubasi dalam inkubator selama 24 jam. Dalam penelitan ini untuk membuktikan bahwa mikroba mikroba ini adalah benar maka dilakukan pengamatan secara makroskopis dan mikroskopis.

\section{Pembuatan suspensi mikroba E.coli, S.aureus, dan Candida albicans}

Biakan mikroba E.coli, S.aureus, dan Candida albicans yang telah dipermuda 24 jam diambil 1 ose dan dilarutkan dalam $\mathrm{NaCl}$ sebanyak $2 \mathrm{ml}$ dan kekeruhan dibandingkan dengan standart kekeruhan Mc Farland 0,5 (mengandung bakteri $10^{8} \mathrm{CFU} / \mathrm{ml}$ ).

\section{Uji Aktivitas Antimikroba menggunakan metode Difusi Cakram}

Kertas cakram dengan diameter $4 \mathrm{~mm}$ dari kertas saring yang dipotong dengan pelubang kertas, dimasukkan dalam cairan ekstrak sesuai dengan konsentrasi masing masing dan didiamkan selama 30 menit selanjutnya kertas cakram dikeluarkan dari cairan ekstrak dan dikeringkan pada suhu sekitar $50^{\circ} \mathrm{C}$ hingga cairan tidak menetes.

Penuangan media Mueller Hinton yang telah disterilkan kedalam petridish. Setelah dingin dan memadat selanjutnya ditanami bakteri E.coli, S.aureus, dan Candida albicans. Selanjutnya diratakan hingga seluruh permukaan media Mueller Hinton dengan menggunakan lidi kapas steril. Cakram diletakkan dalam media Mueller Hinton yang telah ditanami bakteri E.coli, S.aureus, dan Candida albicans, kemudian diinkubasi selama 24 jam pada suhu $37^{\circ} \mathrm{C}$. Aktivitas antimikroba 
Shinta, D.Y., Hartono, A. 2017. Uji Aktivitas Antimikroba Ektrak E.coli, Staphylococcus aureus, dan Candida albicans. Journal of Sainstek. 9(1): 26-39

terbesar ditunjukan oleh luas diameter zona bening terbesar yang terbentuk dari konsentrasi tersebut. Konsentrasi terkecil dari sampel yang mampu menghambat bakteri yang di inokulasikan dengan terbentuknya zona bening merupakan nilai konsentrasi hambat minimum (KHM) dari sampel kulit buah naga. Pengulangan dilakukan sebanyak 3 kali.

\section{HASIL DAN PEMBAHASAN}

Dari hasil penelitian didapatkan ekstrak sereh sebanyak $25 \%$. Zona yang terbentuk pada aktivitas antimikroba dengan metode difusi menunjukkan adanya pengaruh ekstrak Hylocareus costarisensis. Konsentrasi 0,4 $\mathrm{g} / \mathrm{mL} ; 0,8 \mathrm{~g} / \mathrm{mL} ; 1,4 \mathrm{~g} / \mathrm{mL} ; 1,8 \mathrm{~g} / \mathrm{mL} ; 2,00 \mathrm{~g} / \mathrm{Ml}$ terhadap E.coli, Staphylococcus aureus, dan Candida albicans.

Hasil Analisis Ekstrak kulit buah naga menggunakan Kromatografi Gas GC-MS

Data hasil analisis dengan menggunakan kromatografi gas, ditemukan senyawa senyawa yang terkandung di dalam ekstrak kulit buah naga (Hylocareus coatarisensis) adalah sebagai berikut

Tabel 1. Senyawa Senyawa Antimikroba Dalam Ekstrak kulit buah naga

\begin{tabular}{|c|c|c|c|}
\hline No & Waktu Retensi & Senyawa & Persentase(\%) \\
\hline 1 & 1,117 & Acetic acid, hydroxyl (cas)glycolic acid & $40,04 \%$ \\
\hline 2 & 17,803 & $\begin{array}{l}\text { Hexadocanoic acid,2-hydroxy-1,3 } \\
\text { propanediyl ester (cas) glycerol 1,3 } \\
\text { dihexadecanoate }\end{array}$ & $0,23 \%$ \\
\hline 3 & 17.233 & Formic Acid & $2,67 \%$ \\
\hline
\end{tabular}

Dari tabel 1 diatas senyawa-senyawa antimikroba dalam ekstrak kulit buah naga ditemukan 3 senyawa utama dari ekstrak kulit buah naga.Berdasarkan gugus fungsi Hidroksil senyawa di atas dibagi menjadi 2 kelompok yaitu senyawa asam-asam organik dan senyawa kelompok alkohol.Diantaranya 2 senyawa yang mengandung asam asam organik yaitu asam asetat dan asama format dan 1 senyawa kelompok alkohol yaitu fenol. Kosentrasi yang paling tinggi adalah senyawa asam organik Acetic acid, hydroxyl (cas)glycolic acid yaitu $40,04 \%$.

Karakteristik Mikroba Uji
Identifikasi mikroba perlu dilakukan untuk memastikan E.coli, Staphylococcus aureus dan Candida albicans. Seperti yang terlihat pada gambar dibawah ini :

\section{A. Eschericia coli}

Pengamatan secara makroskopis pada E.coli adalah bentuk koloni bulat, ukuran relatif, cembung, pinggiran smooth dan tidak rata.Kemudian untuk pengamatan secara mikroskopis dilakukan pewarnaan Gram dan didapatkan hasil bakteri gram negatif (-) berbentuk batang. Selanjutnya dilakukan uji tes biokimia setelah inkubasi di inkubator selama 1x24 jam, yang hasilnya:

Tabel 2. Hasil INVCMU E.coli

\begin{tabular}{ccccccccc}
\hline $\begin{array}{c}\text { Jenis } \\
\text { Bakteri }\end{array}$ & TSIA & $\begin{array}{c}\text { Simon } \\
\text { Citrate }\end{array}$ & Sulfur & Indol & Motil & Urea & $\begin{array}{c}\text { Metil } \\
\text { Red }\end{array}$ & $\begin{array}{c}\text { Voges } \\
\text { Prokauer }\end{array}$ \\
\hline E. Coli & (A/A) & $(-)$ & $(+)$ & $(+)$ & $(+)$ & $(-)$ & $(+)$ & $(-)$ \\
\hline
\end{tabular}


Shinta, D.Y., Hartono, A. 2017. Uji Aktivitas Antimikroba Ektrak E.coli, Staphylococcus aureus, dan Candida albicans. Journal of Sainstek. 9(1): 26-39

Selanjutnya bakteri ini yang telah penelitian selanjutnya. diyakini sebagai E.coli dapat digunakan pada

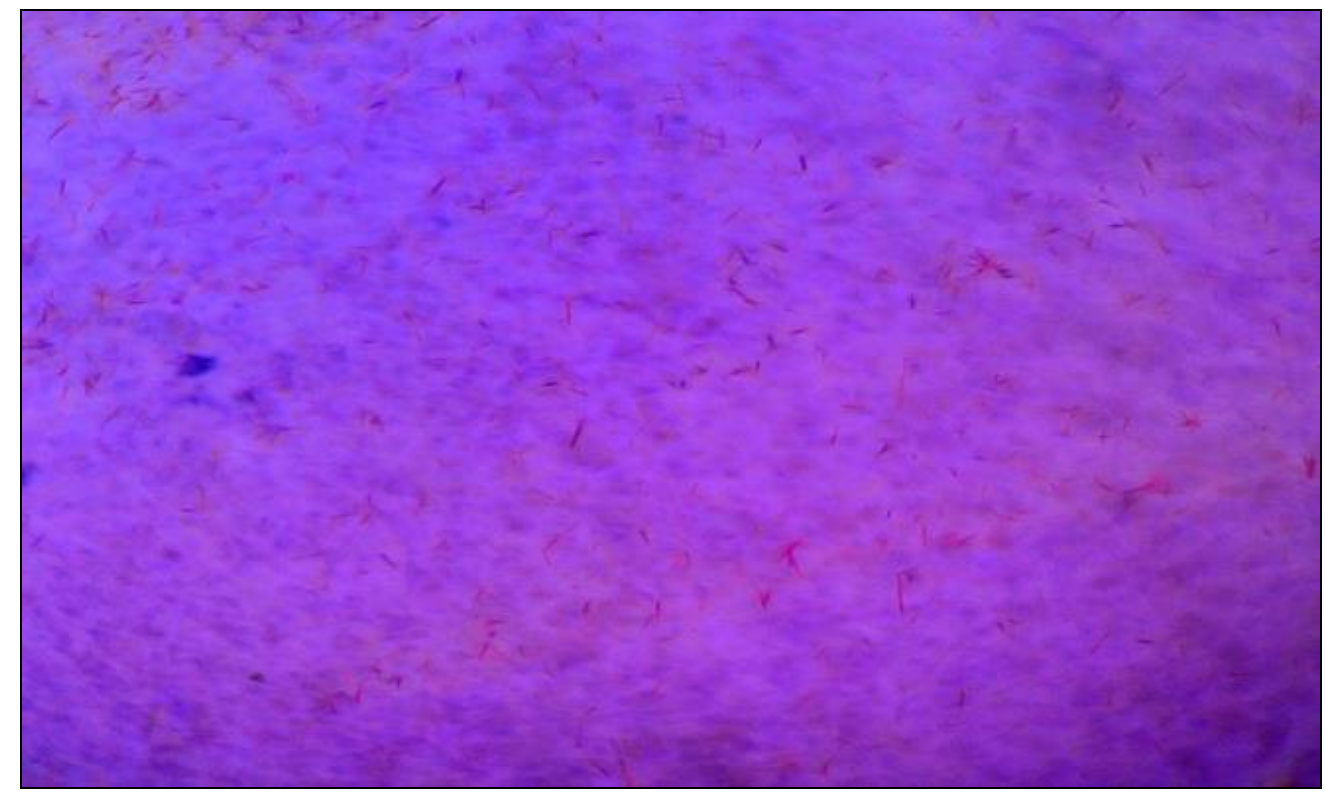

Gambar 1 Pewarnaan Gram pada E.coli

Pada bakteri E.coli, koloninya tersusun seperti rantai memanjang.Pada bakteri ini tidak ditemukan endospora, pada saat diwarnai menunujukkan warna merah. Pengamatan E.coli tersebut menggunakan lensa $100 \mathrm{x}$.

\section{B. Stapylococcus aureus}

Hasil pengamatan secara makroskopis pada bakteri Stapylococcus aureusmenunjukkan koloni bewarna kuning, sedang, bulat, cembung, rata, kering.Selanjutnya dilakukan tes gula-gula

Tabel 3. Hasil Tes Gula GulaStapylococcus aureus

\begin{tabular}{cccccccc}
\hline $\begin{array}{c}\text { Jenis } \\
\text { Bakteri }\end{array}$ & Glukosa & Sukrosa & Mannitol & Katalase & Koagulase & novobiosin & Hemolisa \\
\hline S.aureus & + & + & + & + & + & S & Beta \\
\hline
\end{tabular}

Untuk memastikan spesies bakteri maka dilakukan Tes katalase dan hasilnya adalah positif $(+)$, kemudian dilanjutkan dengan tes koagulase dan hasilnya adalah positif (+), dengan demikian di yakini bahwa bakteri tersebut adalah Stapylococcus aureus. 


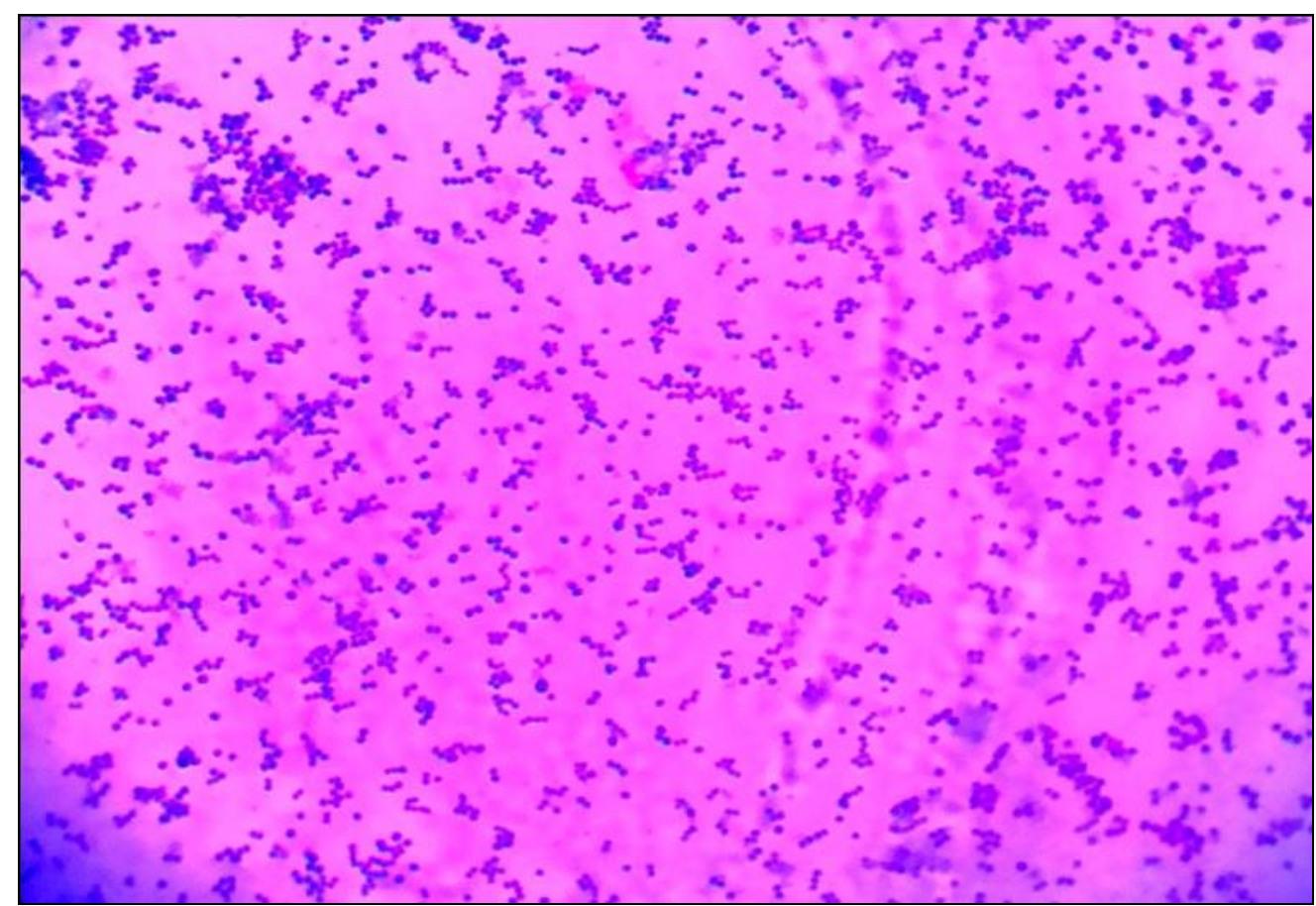

Gambar 2. Pewarnaan Gram pada Staphylococcus aureus

Jika dilakukan tes kepekaan dengan Novobiosin $10 \mathrm{mg}$ maka hasilnya adalah Sensitif dengan Beta hemolisa.Tes gula gula pada Stapylococcus aureusmenunjukkan positif pada Glukosa, Sukrosa dan mannitol.

\section{Candida albicans}

Pengamatan secara makroskopis pada Candida albicans menunjukkan koloni koloni lunak bewarna krem yang mempunyai bau seperti ragi. Pengamatan mikroskopis pada Candida albicans dilakukan dengan cara mengambil satu tetes lacto phenol kemudian ditambah satu tetes koloni Candida albicans yang telah di encerkan dengan aquades. Kemudian ditutup dengan deck glass dan diamati di bawah mikroskop dengan lensa $40 \mathrm{x}$. Namun pada penelitian ini hanya dilakukan pewarnaan Gram.

Tabel 4. Hasil Tes Gula Gula padaCandida albicans

\begin{tabular}{ccccccc}
\hline Jenis Bakteri & $\begin{array}{c}\text { Cornmeal } \\
\text { agar }\end{array}$ & Dextrosa & Galaktosa & Laktosa & Maltosa & Sukrosa \\
\hline Candida albicans & + & + & + & - & + & + \\
\hline
\end{tabular}




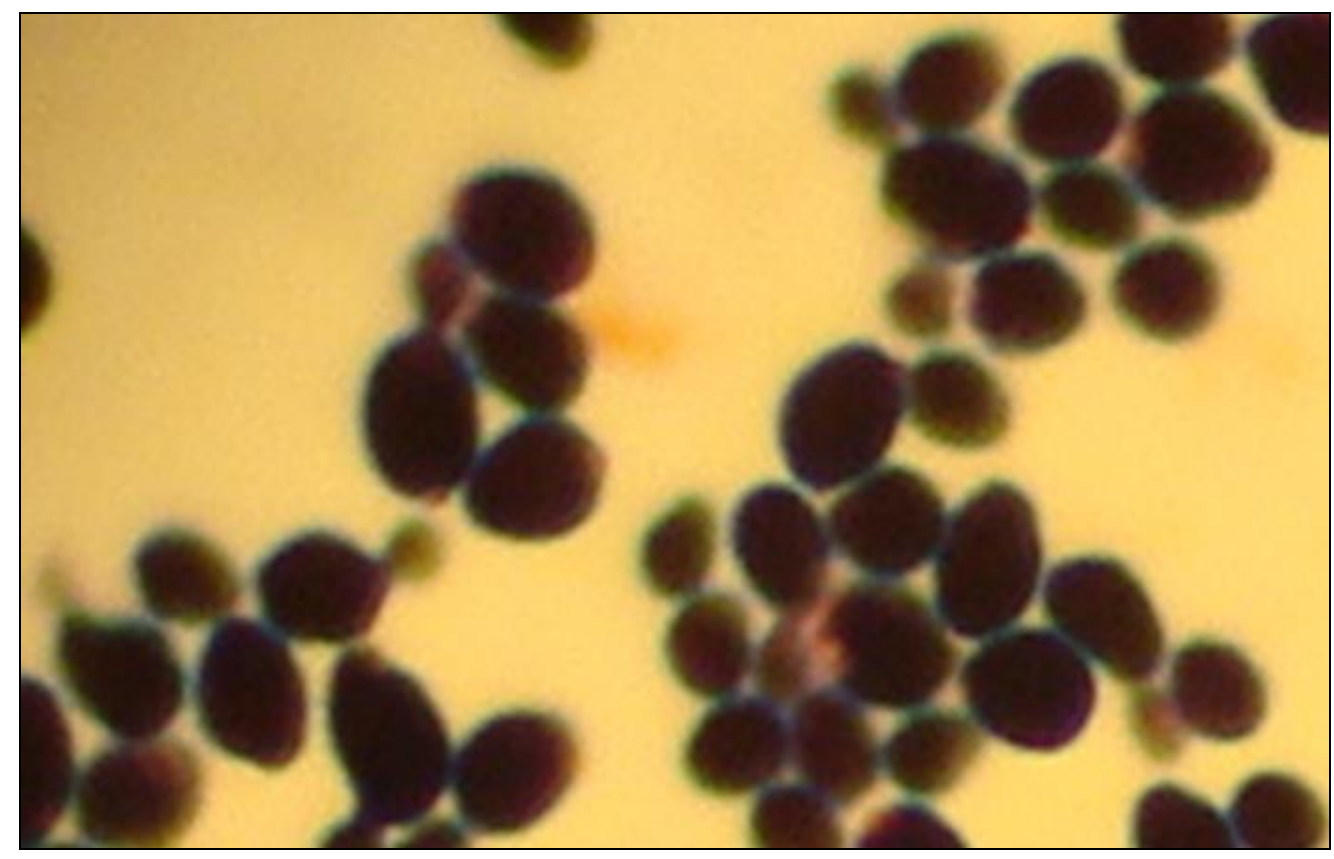

Gambar 3. Mikroskopis dari Candida albicans

Hasil pengamatan secara makroskopis adalah ukuran koloni 2-3 x 4-6 $\mu \mathrm{m}$, sel sel bertunas, bentuk seperti suatu ragi lonjong dan memanjang menyerupai hifa (pseudohifa).Candida albicansyang di tanam pada media PDA (Potato Dextrose Agar)akan memperlihatkan koloni berbentuk bulat dengan permukaan cembung yang pada awalnya menyerupai staphylococci, bewarna putih hingga krem, halus, berbentuk pasta, mempunyai bau jamur.Candida albicansmeragi glukosa dan maltosa, menghasilkan asam dan gas, menghasilkan asam dari sukrosa dan tidak bereaksi dengan laktosa.

\section{Uji Daya Hambat Ekstrak Hylocareus costarisensis terhadap E.coli, Staphylococcus aureus dan Candida albicans}

Hasil maserasi ekstrak kulit buah naga dibuat dalam beberapa konsentrasi,yaitu konsentrasi 0,4 gr ,0,8 gr ,1,4 gr ,1,8 gr ,2.0 gr kemudian diinkubasi pada suhu $37^{\circ} \mathrm{C}$ selama 24 jam.Variasi konsentrasi ini dibuat untuk mengetahui konsentrasi yang paling efektif dalam menghambat pertumbuhan mikroba patogen E.coli, Staphylococcus aureus dan Candida albicans. Zona yang terbentuk pada aktivitas antimikroba dengan metode difusi cakram menunjukkan adanya pengaruh ekstrakHylocareus costarisensisterhadap mikroba uji dan dapat dilihat sebagai berikut :

\section{Hasil Uji Aktivitas Antimikroba ekstrak} Hylocareus costarisensis Pada E.coli Uji aktivitas antimikroba pada E.coli menunjukkan adanya diameter zona hambat pada variasi dosis yang diberikan. Diameter zona hambat terbesar pada dosis 2,0 gr dengan diameter $11 \mathrm{~mm}$. Sedangkan zona hambat terkecil pada dosis 0,4 gr yaitu $7,5 \mathrm{~mm}$. 
Shinta, D.Y., Hartono, A. 2017. Uji Aktivitas Antimikroba Ektrak E.coli, Staphylococcus aureus, dan Candida albicans. Journal of Sainstek. 9(1): 26-39

Tabel 5. hasil daya hambat ektrak kulit buah naga terhadapE.coli

\begin{tabular}{cccccc}
\hline Percobaan & \multicolumn{5}{c}{ Dosis } \\
\cline { 2 - 5 } & $0,4 \mathrm{gr}$ & $0,8 \mathrm{gr}$ & $1,4 \mathrm{gr}$ & $1,8 \mathrm{gr}$ & $2,00 \mathrm{gr}$ \\
\hline 1 & $8 \mathrm{~mm}$ & $8 \mathrm{~mm}$ & $8,5 \mathrm{~mm}$ & $9 \mathrm{~mm}$ & $10 \mathrm{~mm}$ \\
2 & $8 \mathrm{~mm}$ & $8 \mathrm{~mm}$ & $9 \mathrm{~mm}$ & $10 \mathrm{~mm}$ & $10 \mathrm{~mm}$ \\
3 & $7,5 \mathrm{~mm}$ & $8,5 \mathrm{~mm}$ & $9 \mathrm{~mm}$ & $9 \mathrm{~mm}$ & $11 \mathrm{~mm}$ \\
$\sum$ & $23,5 \mathrm{~mm}$ & $24,5 \mathrm{~mm}$ & $26,5 \mathrm{~mm}$ & $28 \mathrm{~mm}$ & $31 \mathrm{~mm}$ \\
Rata-rata & $7,8333 \mathrm{~mm}$ & $8,1666 \mathrm{~mm}$ & $8,8333 \mathrm{~mm}$ & $9,3333 \mathrm{~mm}$ & $10,3333 \mathrm{~mm}$ \\
SD & $0,288 \mathrm{~mm}$ & $0,287 \mathrm{~mm}$ & $0,288 \mathrm{~mm}$ & $0,577 \mathrm{~mm}$ & $0,577 \mathrm{~mm}$ \\
\hline
\end{tabular}

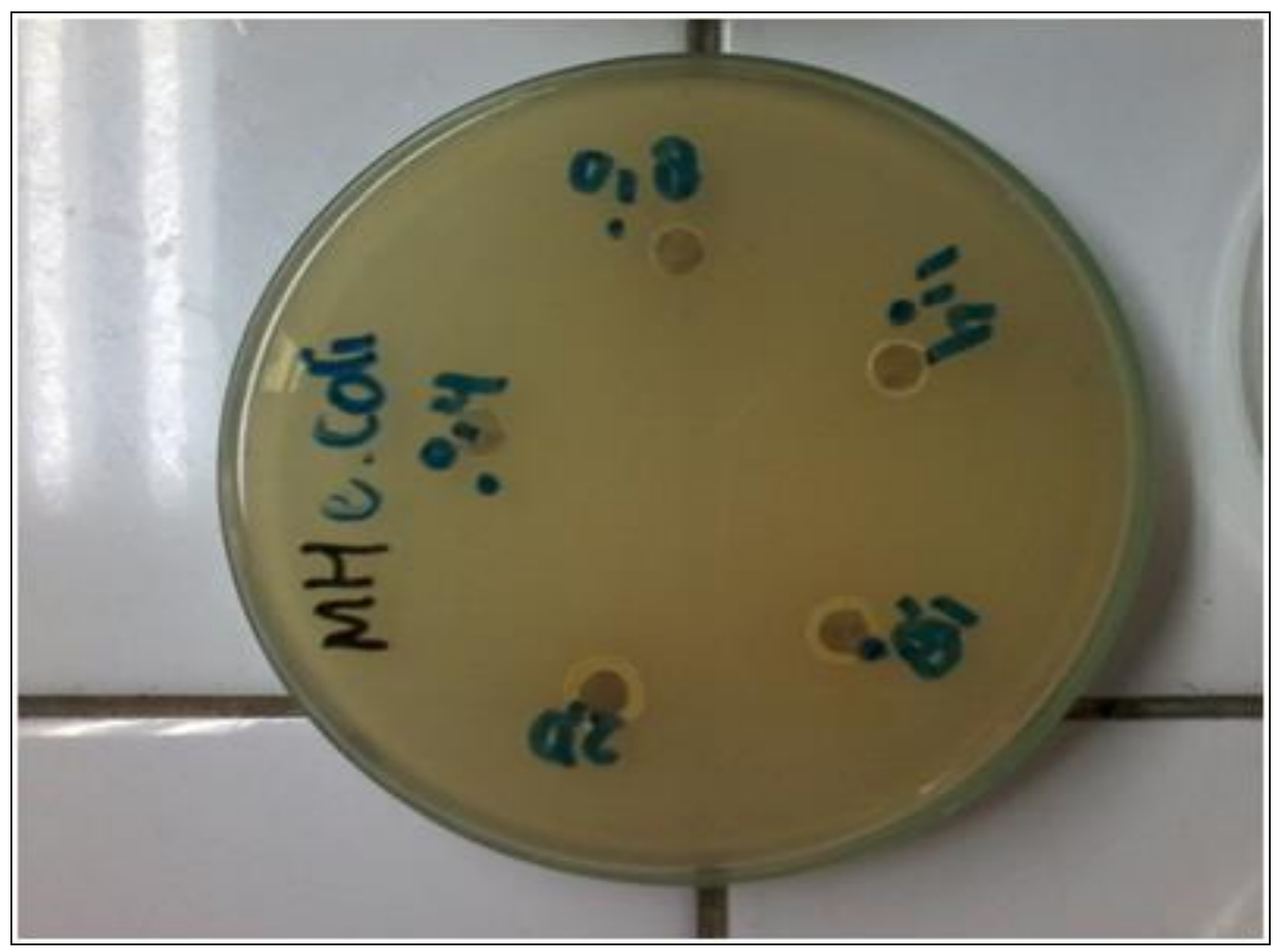

Gambar 4. Hasil Uji Aktivitas Antimikroba ekstrak Hylocareus costarisensis pada E.coli.

Hal tersebut menunjukkan semakin tinggi konsentrasi yang diberikan maka semakin besar zona hambat yang terbentuk. Zona hambat yang terbentuk dapat dikategorikan "sedang". Pengulangan yang dilakukan sebanyak tiga kali karena dalam uji mikrobiologi minimal pengulangan dilakukan sebanyak lima kali atau sebanyak 3 kali pengulangan. Pengulangan dilakukan dengan menggunakan sampel yang sama dan media yang sama yaitu Mueller Hinton.

\section{Hasil Uji Aktivitas Antimikroba Ekstrak Hylocareus costarisensis pada Staphylococcus aureus \\ Uji aktivitas antimikroba pada} Staphylococcus aureus menunjukkan adanya diameter zona hambat pada variasi dosis yang diberikan. Diameter zona hambat terbesar pada dosis 2,0 gr dengan diameter $9 \mathrm{~mm}$. Sedangkan zona hambat terkecil pada dosis 0,4 gr yaitu 6 $\mathrm{mm}$. 
Shinta, D.Y., Hartono, A. 2017. Uji Aktivitas Antimikroba Ektrak E.coli, Staphylococcus aureus, dan Candida albicans. Journal of Sainstek. 9(1): 26-39

Tabel 6. Hasil daya hambat ektrak kulit buah naga terhadap Staphylococus aureus

\begin{tabular}{cccccc}
\hline Percobaan & \multicolumn{5}{c}{ Dosis } \\
\cline { 2 - 6 } & $\mathbf{0 , 4} \mathbf{g r}$ & $\mathbf{0 , 8} \mathbf{~ g r}$ & $\mathbf{1 , 4} \mathbf{~ g r}$ & $\mathbf{1 , 8} \mathbf{~ g r}$ & $\mathbf{2 , 0 0} \mathbf{g r}$ \\
\hline 1 & $7 \mathrm{~mm}$ & $7 \mathrm{~mm}$ & $8 \mathrm{~mm}$ & $8 \mathrm{~mm}$ & $9 \mathrm{~mm}$ \\
2 & $6 \mathrm{~mm}$ & $7 \mathrm{~mm}$ & $7 \mathrm{~mm}$ & $8 \mathrm{~mm}$ & $8 \mathrm{~mm}$ \\
3 & $7,5 \mathrm{~mm}$ & $8 \mathrm{~mm}$ & $8,5 \mathrm{~mm}$ & $9 \mathrm{~mm}$ & $9 \mathrm{~mm}$ \\
$\sum$ & 20,5 & 22 & 23,5 & 25 & 26 \\
Rata-Rata & $6,8333 \mathrm{~mm}$ & $7,3333 \mathrm{~mm}$ & $7,8333 \mathrm{~mm}$ & $8,3333 \mathrm{~mm}$ & $8,6666 \mathrm{~mm}$ \\
SD & $0,762 \mathrm{~mm}$ & $0,577 \mathrm{~mm}$ & $0,762 \mathrm{~mm}$ & $0,577 \mathrm{~mm}$ & $0,577 \mathrm{~mm}$ \\
\hline
\end{tabular}

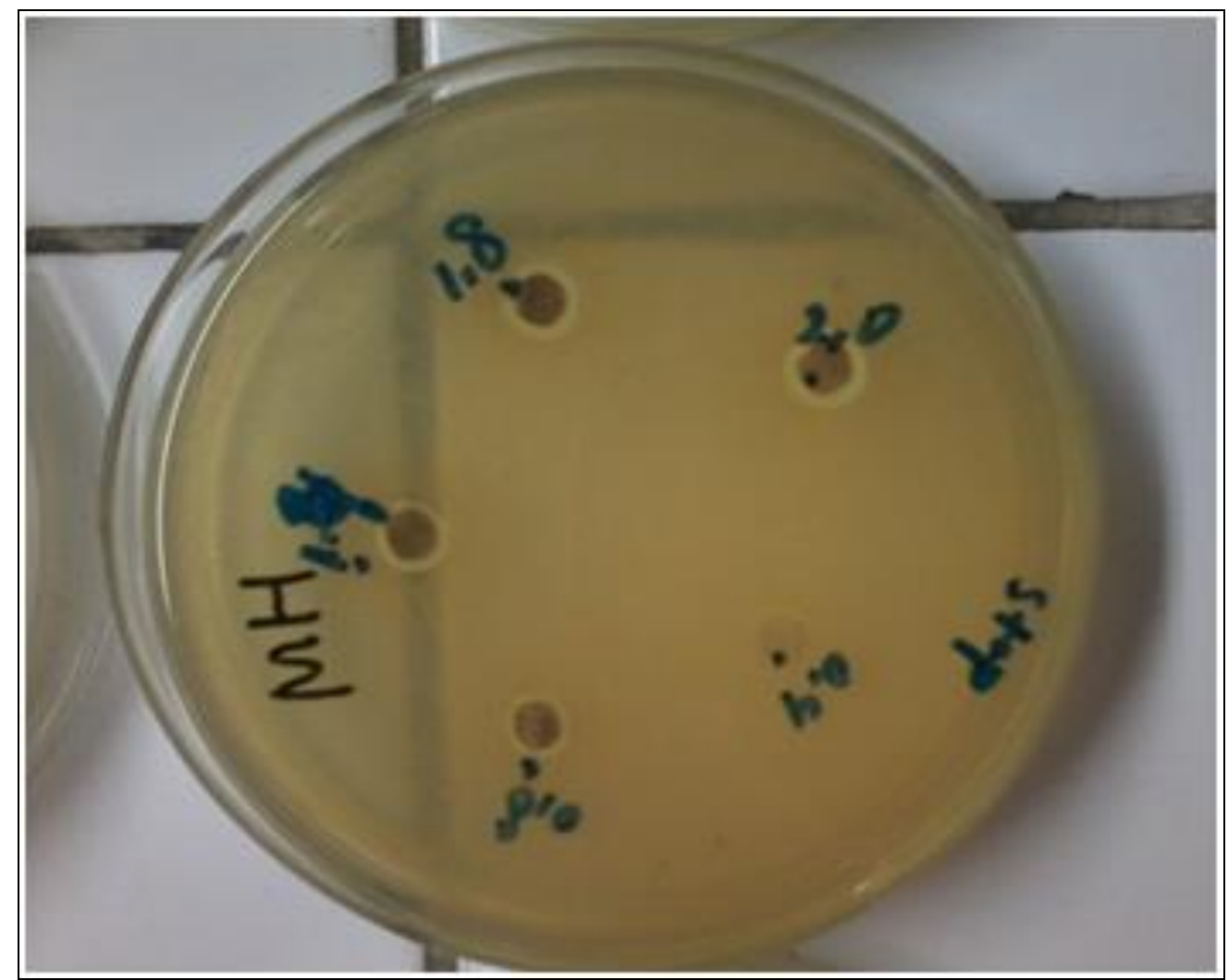

Gambar 5. Hasil Uji Aktivitas Antimikroba Ekstrak Hylocareus costarisensis pada Staphylococcus aureus

Hal tersebut menunjukkan semakin tinggi konsentrasi yang diberikan maka semakin besar zona hambat yang terbentuk.Zona hambat yang terbentuk dapat dikategorikan "sedang". Pengulangan yang dilakukan sebanyak tiga kali karena dalam uji mikrobiologi minimal pengulangan dilakukan sebanyak lima kali atau sebanyak 3 kali pengulangan. Pengulangan dilakukan dengan menggunakan sampel yang sama dan media yang sama yaitu Mueller Hinton.

\section{Hasil Uji Aktivitas Antimikroba Ekstrak Hylocareus PadaCandida albicans \\ costarisensis}


Shinta, D.Y., Hartono, A. 2017. Uji Aktivitas Antimikroba Ektrak E.coli, Staphylococcus aureus, dan Candida albicans. Journal of Sainstek. 9(1): 26-39

Uji aktivitas antimikroba pada Candida albicans menunjukkan adanya diameter zonahambat pada variasi dosis yang diberikan. Diameter zona hambat terbesar pada dosis 2,0 gr dengan diameter $9 \mathrm{~mm}$. Sedangkan zona hambat terkecil pada dosis 0,4 gr yaitu $6 \mathrm{~mm}$.

Tabel 7. hasil daya hambat ektrak kulit buah naga terhadap Candida albicans

\begin{tabular}{cccccc}
\hline Percobaan & \multicolumn{5}{c}{ Dosis } \\
\cline { 2 - 5 } & $\mathbf{0 , 4} \mathbf{~ g r}$ & $\mathbf{0 , 8} \mathbf{g r}$ & $\mathbf{1 , 4} \mathbf{g r}$ & $\mathbf{1 , 8} \mathbf{~ g r}$ & $\mathbf{2 , 0 0} \mathbf{g r}$ \\
\hline 1 & $6 \mathrm{~mm}$ & $6 \mathrm{~mm}$ & $6 \mathrm{~mm}$ & $7 \mathrm{~mm}$ & $7 \mathrm{~mm}$ \\
2 & $6 \mathrm{~mm}$ & $7 \mathrm{~mm}$ & $7 \mathrm{~mm}$ & $7 \mathrm{~mm}$ & $8 \mathrm{~mm}$ \\
3 & $6 \mathrm{~mm}$ & $7 \mathrm{~mm}$ & $6 \mathrm{~mm}$ & $7 \mathrm{~mm}$ & $8 \mathrm{~mm}$ \\
$\sum$ & $18 \mathrm{~mm}$ & $20 \mathrm{~mm}$ & $19 \mathrm{~mm}$ & $21 \mathrm{~mm}$ & $23 \mathrm{~mm}$ \\
Rata-rata & $6 \mathrm{~mm}$ & $6,6666 \mathrm{~mm}$ & $6,3333 \mathrm{~mm}$ & $7 \mathrm{~mm}$ & $7,6666 \mathrm{~mm}$ \\
SD & & $0,576 \mathrm{~mm}$ & $0,576 \mathrm{~mm}$ & & $0,577 \mathrm{~mm}$ \\
\hline
\end{tabular}

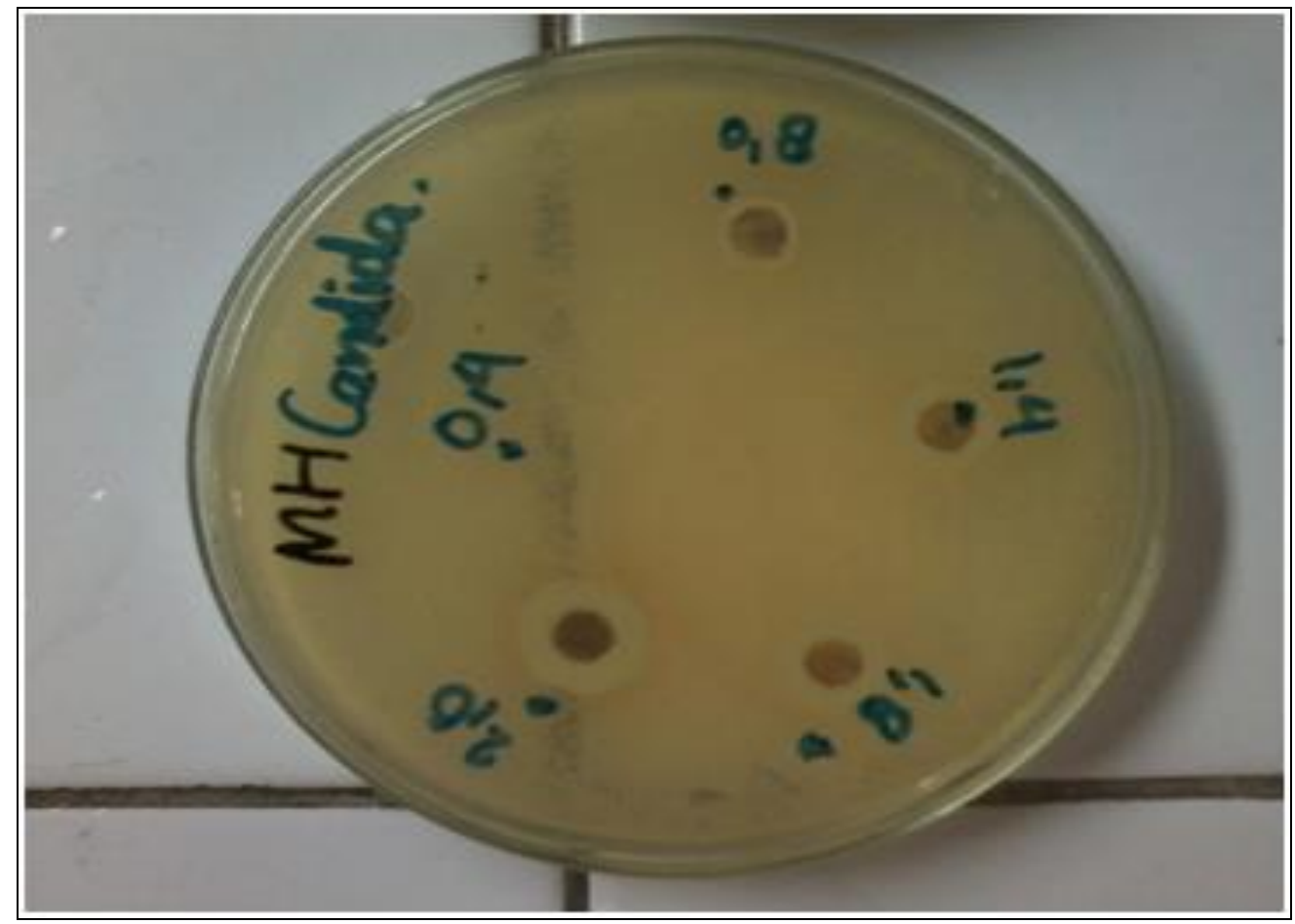

Gambar 6. Hasil Uji Aktivitas Antimikroba Ekstrak Hylocareus costarisensis pada Candida albicans

Hal tersebut menunjukkan semakin tinggi konsentrasi yang diberikan maka semakin besar zona hambat yang terbentuk.Zona hambat yang terbentuk dapat dikategorikan sedang.
Pengulangan yang dilakukan sebanyak tiga kali karena dalam uji mikrobiologi minimal pengulangan dilakukan sebanyak lima kali atau sebanyak 3 kali pengulangan. Pengulangan 
Shinta, D.Y., Hartono, A. 2017. Uji Aktivitas Antimikroba Ektrak E.coli, Staphylococcus aureus, dan Candida albicans.

dilakukan dengan menggunakan sampel yang sama dan media yang sama yaitu Mueller Hinton.

\section{Analisis Data}

Perhitungan daya hambat ekstrak kulit buah naga terhadap E.coli, Staphylococcus aureus dan candida albicans, maka dilakukan uji anova satu arah dengan metode SPSS 16 (Stastistical Program Social Science).

\section{Hasil Analisis Ekstrak kulit buah naga menggunakan Kromatografi Gas GC-MS}

Data hasil analisis dengan menggunakan kromatografi gas,ditemukan senyawa senyawa yang terkandung di dalam ekstrak kulit buah naga (Hylocareus coatarisensis) adalah sebagai berikut :

Table 8. Senyawa Senyawa Antimikroba Dalam Ekstrak kulit buah naga

\begin{tabular}{cclc}
\hline No & Waktu Retensi & \multicolumn{1}{c}{ Senyawa } & Persentase(\%) \\
\hline 1 & 1,117 & Acetic acid, hydroxyl (cas)glycolic acid & $40,04 \%$ \\
2 & 17,803 & $\begin{array}{l}\text { Hexadocanoic acid,2-hydroxy-1,3 propanediyl } \\
\text { ester (cas) glycerol 1,3 dihexadecanoate }\end{array}$ & $0,23 \%$ \\
3 & 17.233 & Formic Acid & $2,67 \%$ \\
\hline
\end{tabular}

Dari tabel 4.1 senyawa-senyawa antimikroba dalam ekstrak kulit buah naga ditemukan 3 senyawa utama dari ekstrak kulit buah naga.Berdasarkan gugus fungsi Hidroksil senyawa di atas dibagi menjadi 2 kelompok yaitu senyawa asam-asam organik dan senyawa kelompok alkohol.Diantaranya 2 senyawa yang mengandung asam asam organik yaitu asam asetat dan asama format dan 1 senyawa kelompok alkohol yaitu fenol. Kosentrasi yang paling tinggi adalah senyawa asam organik Acetic acid, hydroxyl (cas)glycolic acid yaitu $40,04 \%$.

\begin{abstract}
Analisis Data
Perhitungan daya hambat ekstrak kulit buah naga terhadap E.coli, Staphylococcus aureus dan candida albicans, maka dilakukan uji anova satu arah dengan metode SPSS 16 (Stastistical Program Social Science)

Untuk mengetahui ada/tidaknya perbedaan diameter zona hambat yang signifikan, maka dilakukan analisis statistik dengan menggunakan uji one-way ANOVA.
\end{abstract}

\section{E. coli}

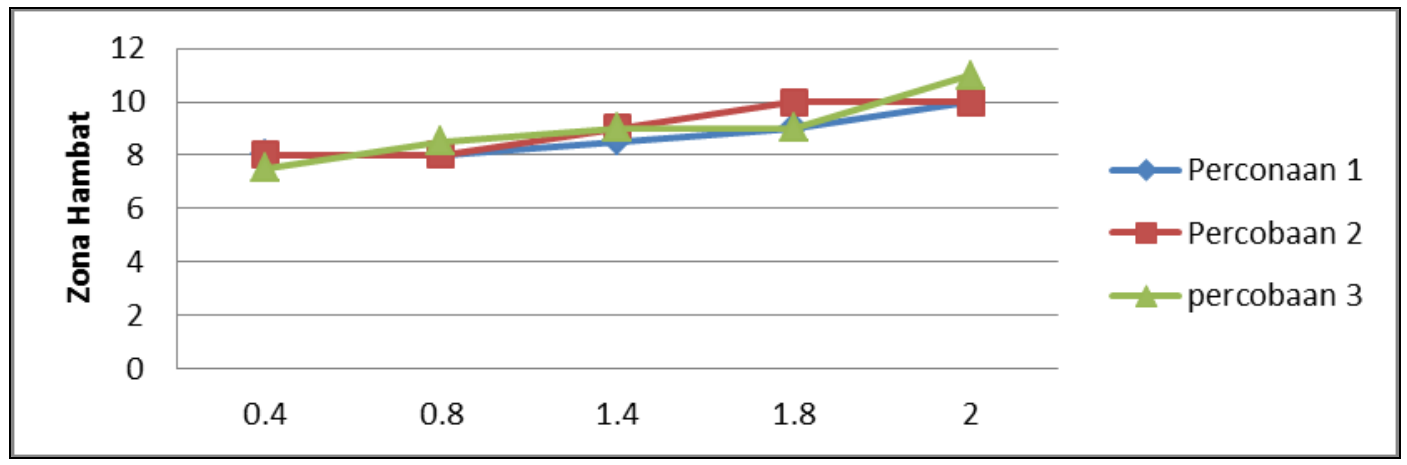

Gambar 7. E. coli 
Shinta, D.Y., Hartono, A. 2017. Uji Aktivitas Antimikroba Ektrak E.coli, Staphylococcus aureus, dan Candida albicans. Journal of Sainstek. 9(1): 26-39

Dari data di atas menunjukkan bahwa uji aktivitas antimikroba pada E.coli menunjukkan adanya diameter zona hambat pada variasi dosis yang diberikan. Diameter zona hambat terbesar pada dosis 2,0 gr dengan diameter $11 \mathrm{~mm}$. Sedangkan zona hambat terkecil pada dosis 0,4 gr yaitu $7,5 \mathrm{~mm}$.

\section{Staphylococcus aureus}

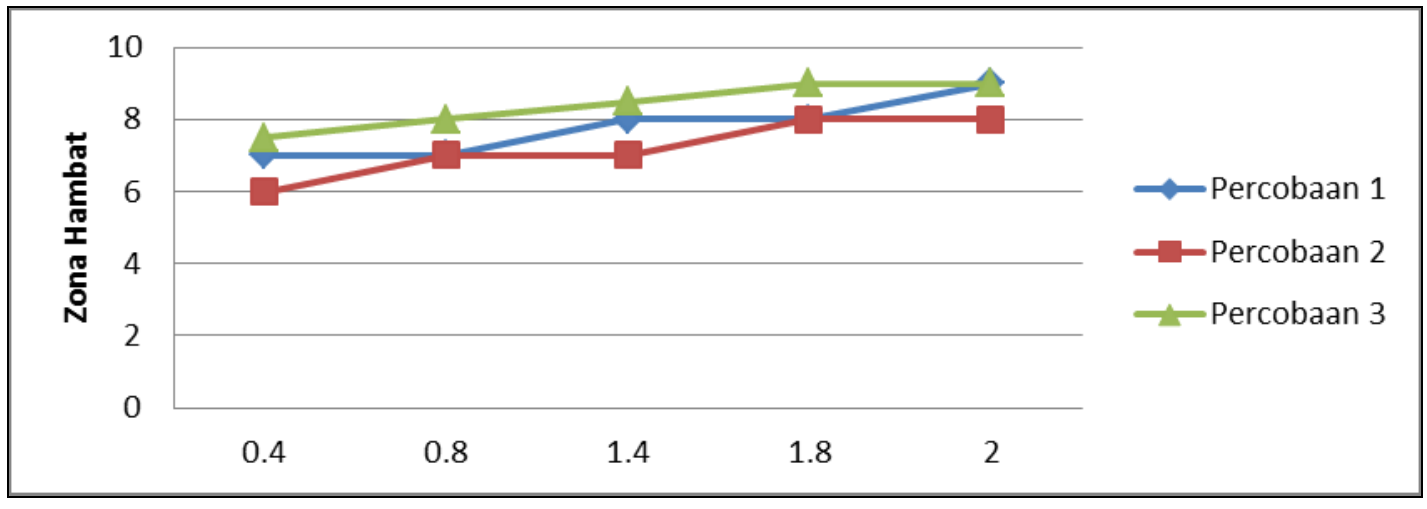

Gambar 8. Staphylococcus aureus

Dari data di atas menunjukkan bahwa uji aktivitas antimikroba pada Staphylococcus aureus menunjukkan adanya diameter zona hambat pada variasi dosis yang diberikan.
Diameter zona hambat terbesar pada dosis 2,0 gr dengan diameter $9 \mathrm{~mm}$. Sedangkan zona hambat terkecil pada dosis 0,4 gr yaitu $6 \mathrm{~mm}$.

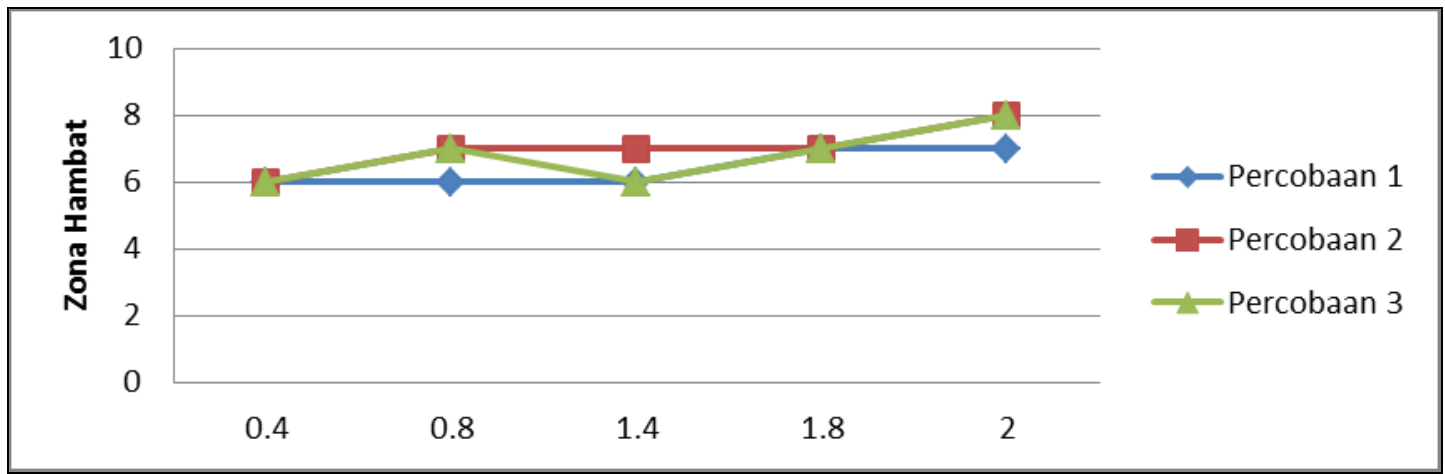

Gambar 9. Candida albicans

Dari data di atas menunjukkan bahwa uji aktivitas antimikroba pada Candida albicans menunjukkan adanya diameter zonahambat pada variasi dosis yang diberikan. Diameter zona hambat terbesar pada dosis 2,0 gr dengan diameter $9 \mathrm{~mm}$. Sedangkan zona hambat terkecil pada dosis 0,4 gr yaitu $6 \mathrm{~mm}$.
Metode yang digunakan untuk mengevaluasi aktivitas antibakteri dari ekstrak Hylocareus costarisensis terhadap mikroba $E$. coli, Staphylococcus aureus, Candida albicans, adalah metode difusi agar, oleh karena metode ini paling umum digunakan untuk menentukan 
Shinta, D.Y., Hartono, A. 2017. Uji Aktivitas Antimikroba Ektrak E.coli, Staphylococcus aureus, dan Candida albicans.

Journal of Sainstek. 9(1): 26-39

suseptibilitas dari mikroba terhadap bahan yang diuji (Tobias, 1988 ; Mickel et all, 2003).

Untuk mendapatkan ekstrak Hylocareus costarisensis yang akan digunakan dalam penelitian, digunakan alat rotary vakum evaporator. Prinsip utama dalam instrumen ini terletak pada penurunan tekanan pada labu alas bulat dan pemutaran labu alas bulat hingga berguna agar pelarut dapat menguap lebih cepat dibawah titik didihnya. Rotary vakum evaporator memiliki teknik yang lebih unggul dibandingkan alat ekstraksi lainnya yaitu, suatu pelarut akan menguap dan senyawa yang larut dalam pelarut tersebut tidak ikut menguap namun mengendap. Dan dengan pemanasan dibawah titik didih pelarut, sehingga senyawa yang terkandung dalam pelarut tidak rusak oleh suhu tinggi.

Pemberian konsentrasi yang berbedabeda menunjukkan pengaruh yang berbeda pula terhadap zona hambatan yang dihasilkan. Semakin luas daerah zona hambatan yang terbentuk di sekitar paper disk, maka semakin besar pula daya antimikroba yang terdapat pada ekstrak Hylocareus costarisensis. Hal ini sejalan dengan Jawetz (1986) yang menyatakan bahwa wilayah jernih disekitar zat antimikroba merupakan kekuatan hambatan zat antimikroba terhadap penghambatan pertumbuhan mikroorganisme. Ini ditunjukkan dengan adanya zona hambatan atau daerah transparan di sekitar paper disk pada pertumbuhan mikroba E. coli, Staphylococcus aureus, Candida albicans.

Hasil uji statistika dengan menggunakan anova menunjukkan terdapat daya hambat dari ekstrak kulit buah naga terhadap E. coli, Staphylococus aureus dan Candida albicans. Hal ini disebabkan oleh adanya zat antimikroba pada ekstrak kulit buah naga yaitu fenol, asam asetat, dan asam format. Mekanisme fenol dalam membunuh sel mikroba yaitu dengan mendenaturasi protein sel bakeri yang mengakibatkan semua aktivitas metabolisme sel mikroba terhenti, karena aktivitas metabolisme sel mikroba telah dikatalisis oleh enzim yang merupakan protein (Kusdawarti et al,2010). Salah satu aktivitas antimikroba dari asam organik antara lain berasal dari asam asetat. Aktivitas ini ditentukan oleh besarnya nilai $\mathrm{pKa}$ yang merupakan presentase molekul asam yang tidak terdisosiasi. Kondisi derajat asam rendah serta banyaknya asam organik yang tidak terdisosiasi akan meningkatkan kemampuan sebagai antimikroba (Ray, 1992). Pada beberapa Jurnal kesehatan menjelaskan bahwa asam format juga memiliki potensi sebagai antimikroba.

\section{KESIMPULAN}

1. Setelah dilakukan penelitian didapatkan hasil daya hambat ekstrak hylocareus costarisensis (kulit buah naga) mampu menghambat pertumbuhan bakteri E.coli, Staphylococcus aureus dan jamur Candida albicans yang di pengaruhi oleh kandungan kimia yang memilki peran sebagai antimkroba salah satunya yaitu asam asam organik seperti asam asetat dan asam format dan kelompok alkohol berupa fenol yang terdapat pada ekstrak Hylocareus costarisensis.

2. Adanya daya hambat pada mikroba ini karena mempunyai pengaruh yang signifikan dan tidak signifikan. Ekstrak hylocareus costarisensis (kulit buah naga) mampu menghambat pertumbuhan mikroba E.coli, Staphylococcus aureus dan Candida albicans. Peningkatan konsentrasi ekstrak hylocareus costarisensis (kulit buah naga) berpengaruh terhadap peningkatan kemampuan efek antimikroba.

\section{DAFTAR KEPUSTAKAAN}

Aldi Y. 2009. Pengetahuan Media Reagensia 1. Padang: Prodi DII Analis Kesehatan Stikes Perintis Padang..

Bergey DH, Holt JG, Krieg NR \& Sneath, PHA 1998. Bergey's Manual Of Determinative Bacteriology.Edisi ke-9.Lippincot William dan Wilkin, Philadelphia.

Brooks GF, Butel JS, and Ornston N. 1995. Medical Microbiology. 4th ed. 
Conecticut: Appleton \& Lange, Simon \& Schuster Company. p.197-202.

Darlimartha S. 1999. Atlas Tumbuhan Obat Indonesia. Jilid 1. Jakarta: Trubus Agriwidya,

Departemen Kesehatan Direktorat Jendral Pelayanan Medik Direktorat Laboratorium Kesehatan. 2003. Prosedur Pemeriksaan Laboratorium Mikrobiologi. Jakarta.

Duta GN, Gogoi J, Buragohain and Jyoti. . 2001. Inactivation of Chloramphenicol by Staphylococcus aureus biotype C from humans and animal.

Fischetti AV, Novick RP, Ferreti JJ, Portnoy DA, and Rood JI. 2000. Gram Positif. Washington DC: ASM Press. p.315

Fluit C. 2001. Molekular Detection of Antimicrobial Resistance.

Ingram LO. 1981. Mecanism of Lysis E.coli by Ethanol and Other Chaostropic Agents. J of Bacteriology 146(1): 331-335.

Instalasi Patologi Klinik FK UNAIR- RSUD Dr. Soetomo. 2013. Panduan Workshop Mikrobiologi. Surabaya.

Khomsan A, 2006, Solusi Makanan Sehat, Jakarta: raja grafindo Persada.

Lenny S. 2006. Senyawa Flavonoida, Fenilpropanoida, dan Alkaloida. FMIPA Medan: USU.

Madigan MT, Martinko JM, and Parker J. 1997. Biology of Microorganism. Eight ed. USA : Simon \& Schuster, A Viocom Company. p.40-43,70,878.

Martins IM, Cortes JCG, Munoz J. Moreno, B, Ramos M , Clemente JA, Duran A, \& Ribas JC. 2011. Differential Activities of three families of specific $\beta(1,3)$ glucan synthase inhibitors in wild-type and resistant strains of fission yeast. The Journal of biologycal chemistry 286:5:3484-3496.

Mycek MJ, Harvey RA, and Champe PC. 1997. Inhibitor of Cell Wall Synthesis In: Pharmacology. 2nd ed. Philadelphia: Lippincott Williams \& Wikins. p.297310
Noegrohati S. 1997. Dasar dan Aplikasi Kromatografi Gas. UGM. Yogyakarta.

Pelezar MJ, Chan ECS. 1988. Dasar-dasar Mikrobiologi. Jakarta: UI Press.

Pelezar MJ, Chan ECS, Krieg NR. 1993. Microbiology Concepts and Application. New York: Mc Graw-Hill Inc.

Pelezar MJ, Reid RD. 1979. Microbiology. New York: McGraw Hill Book Co.

Pratiwi ST. 2008. Mikrobiologi farmasi. Penerbit Erlangga, Jakarta.

Prescott LM, Harley JP and Klein DA. 2003. Microbiology. 5th ed. New York : Mc Graw Hill. p.809.

Retnoningrum DS. 1998. Mekanisme dan Deteksi Molekuler Resistensi Antibiotika pada Bakteri. Bandung: Farmasi ITB. Hal. 1-5, 16-21.

Robinson RK. 2000. Encyclopedia of food microbiology. Academic Press. London.

Russell AD and Chopra I. 1990. Understanding Antimicrobial Action and Resistance. England: Ellis Horword Limited. p.58,157-159

Ryan KJ, Champoux JJ, Falkow S, Plonde SS, Drew WL, Neidhardt FC and Roy CG. 1994. Medical Microbiology An Introduction to Infectious Diseases. 3rd ed. Connecticut: Appleton\&Lange. p.254.

Suradikusumah E. 1989. Kimia Tumbuhan. Departemen Pendidikan dan Kebudayaan. Direktorat Jendral Pendidikan Tinggi. Pusat Antar Ilmu Hayat. IPB. Bogor

The World Oral Health Report 2003: Continuous improvement of oral health in the 21st century - the approach of the WHO Global Oral Health Programme, released by the World Health Organization. (File in pdfformat.)

Thlstrup A, Fejerskov O, editors. Textbook of Cariology. 1986.

Tortora GJ, Funke BR \& Case, CL. 2001. Microbiology An Introduction. $7^{\text {th }}$ ed. Benjamin Cummings, USA

Tuwindar. 2012.Sensitivitas Terhadap Zat-Zat Antimikroba 
Shinta, D.Y., Hartono, A. 2017. Uji Aktivitas Antimikroba Ektrak E.coli, Staphylococcus aureus, dan Candida albicans. Journal of Sainstek. 9(1): 26-39

Vandepitte J, Verhaegen J, Piot P, Heuck CC. 2011. Prosedur Laboratorium Dasar untuk Bakteriologi Klinis. Edisi 2. Buku Kedokteran EGC. Jakarta.

Waluyo L. 2004. Mikrobiologi Umum. UMM Press, Malang.

Wax GR, Lewis K, Salyer AA, Taber H. 2008. Bacterial Resistance to Antimicrobials
Second Edition. London. New York. CRC Press.

Wilson and Gisvold's, 1982. Textbook of Organic Medical ad Pharmaceutical, 8 th. ED. Jilid Terjemahan Achmad Mustofa Fatah, IKIP Press, Semarang. 